Pesq. Vet. Bras. 30(12):1053-1057, dezembro 2010

\title{
Evidence of mixed persistent infections in calves born to cows challenged with a pool of bovine viral diarrhea virus isolates ${ }^{1}$
}

\author{
Sandra Arenhart ${ }^{2}$, Fernando V. Bauermann², Fernanda S.F. Vogel ${ }^{3}$, \\ Rudi Weiblen ${ }^{3}$ and Eduardo F. Flores ${ }^{3^{*}}$
}

\begin{abstract}
Arenhart S., Bauermann F.V., Vogel F.S.F., Weiblen R. \& Flores E.F. 2010. Evidence of mixed persistent infections in calves born to cows challenged with a pool of bovine viral diarrhea virus isolates. Pesquisa Veterinária Brasileira 30(12):1053-1057. Departamento de Medicina Veterinária Preventiva, Universidade Federal de Santa Maria, Camobi, Santa Maria, RS 97105-900, Brazil. E-mail: eduardofurtadoflores@gmail.com

Pregnant cows infected with noncytopathic (NCP) isolates of bovine viral diarrhea virus (BVDV) between days 40 and 120 days of gestation frequently deliver immunotolerant, persistently infected $(\mathrm{PI})$ calves. We herein report the characterization of $\mathrm{PI}$ calves produced experimentally through inoculation of pregnant cows with a pool of Brazilian BVDV-1 $(n=2)$ and BVDV-2 isolates $(n=2)$ between days 60 and 90 of gestation. Two calves were born virus positive, lacked BVDV antibodies, but died 7 and 15 days after birth, respectively. Six other calves were born healthy, seronegative to BVDV, harbored and shed virus in secretions for up to 210 days. Analysis of the antigenic profile of viruses infecting these calves at birth and 30 days later with a panel of monoclonal antibodies indicated two patterns of infection. Whereas three calves apparently harbored only one isolate (either a BVDV-1 or BVDV-2), co-infection by two antigenically distinct challenge viruses was demonstrated in three $\mathrm{PI}$ calves. Moreover, testing the viruses obtained from the blood of PI calves by an RT-PCR able to differentiate between BVDV-1 and BVDV-2 confirmed the presence/persistence of two co-infecting viruses of different genotypes (BVDV-1 and BVDV-2) in these animals. These findings indicate that persistent infection of fetuses/calves - a well characterized consequence of fetal infection by BVDV - may be established concomitantly by more than one isolate, upon experimental inoculation. In this sense, mixed persistent infections with antigenically distinct isolates may help in understanding the immunological and molecular basis of BVDV immunotolerance and persistence.
\end{abstract}

INDEX TERMS: BVDV, persistent infection, co-infection.

RESUMO.- [Evidências de infecção persistente mista em bezerros nascidos de vacas inoculadas com um pool de isolados do vírus da diarréia viral bovina.] Vacas prenhes infectadas com isolados não-citopáticos (NCP) do vírus da diarréia viral bovina (BVDV) entre os dias 40 e 120 de gestação frequentemente produzem be-

\footnotetext{
${ }^{1}$ Received on April 12, 2010.

Accepted for publication on August 13, 2010.

2 Programa de Pós-Graduação em Medicina Veterinária (PPGMV), Universidade Federal de Santa Maria (UFSM), Av. Roraima 1000, Capus de Camobi, Santa Maria, RS 97105-900, Brazil.

${ }^{3}$ Setor de Virologia, Departamento de Medicina Veterinária Preventiva (DMVP), UFSM, Camobi, Santa Maria, RS. ${ }^{*}$ Corresponding author: eduardofurtadoflores@gmail.com
}

zerros imunotolerantes, persistentemente infectados (PI). Este artigo relata a caracterização de bezerros PI produzidos experimentalmente, pela inoculação de vacas prenhes com um pool de isolados brasileiros de BVDV-1 $(n=2)$ e BVDV-2 ( $n=2)$ entre os dias 60 e 90 de gestação. Dois bezerros nasceram positivos para vírus, negativos para anticorpos, mas morreram aos dias 7 e 15 pós-nascimento, respectivamente. Outros seis bezerros nasceram saudáveis, soronegativos para o BVDV, replicaram e excretaram o vírus em secreções por até 210 dias. Análise antigênica dos vírus presentes nos bezerros $\mathrm{PI}$ com anticorpos monoclonais, ao nascimento e 30 dias após, revelou dois padrões de infecção. Três bezerros apresentavam apenas um dos vírus utilizados no desafio (BVDV-1 
ou BVDV-2), enquanto outros três bezerros apresentavam co-infecção com mais de um vírus. Além disso, testandose o sangue dos animais PI com um PCR capaz de diferenciar entre BVDV-1 e BVDV-2 observou-se a presença concomitante de vírus dos dois genótipos (BVDV-1 e BVDV-2) nestes três animais. Esses resultados indicam que infecção persistente - uma consequência bem conhecida da infecção fetal pelo BVDV - pode ser estabelecida concomitantemente por mais de um vírus, após infecção experimental. Nesse sentido, infecções persistentes mistas com isolados antigenicamente distintos podem ser úteis para o estudo das bases imunológicas e moleculares da imunotolerância e infecção persistente pelo BVDV.

TERMOS DE INDEXAÇÃO: BVDV, infecção persistente, coinfecção.

\section{INTRODUCTION}

Bovine viral diarrhea virus (BVDV) is a widespread pathogen of cattle associated with a wide range of clinical manifestations, ranging from subclinical infections to severe and fatal disease (Baker 1995). BVDV is a small, enveloped, positive sense RNA virus belonging to the family Flaviviridae, genus Pestivirus (Fauquet et al. 2005). Field BVDV isolates display a remarkable antigenic variation and two antigenically distinct genotypes were first recognized and named BVDV1 and BVDV-2 (Pellerin et al. 1994, Ridpath et al. 1994). Lately, the classification of BVDV-1 and BVDV-2 as different virus species has been adopted by the International Committee of Taxonomy of Viruses (ICTV) (Fauquet et al. 2005). In addition, the two BVDV genotypes (or virus species) may be further subdivided in subgenotypes (Pellerin et al. 1994, Flores et al. 2002, Ridpath 2003). A third BVDV species, named BVDV-3 or atypical bovine pestivirus has been recently proposed (Liu et al. 2009). Viruses from different genotypes may be differentiated genetically by nucleotide sequencing and comparison of conserved genome sequences, noticeably the 5' untranslated region (5'UTR) of the viral genome (Pellerin et al. 1994, Ridpath et al. 1994, Ridpath \& Bolin 1998). BVDV-1 and BVDV-2 isolates may also be differentiated antigenically, by monoclonal antibody binding and virus neutralizing assays (Fulton et al. 1997, Ridpath 2003). In general, serological cross-reactivity and neutralization between BVDV-1 and BVDV-2 is low. Therefore, $B V D V$ vaccines should contain viruses from both genotypes, and, if needed, from different subgenotypes as well (Fulton et al. 2003). In addition to genetic and antigenic variation, two biotypes of BVDV exist in nature, noncytopathic (NCP) and cytopathic (CP), classified based on the effects of virus replication in cultured cells (Ridpath 2003).

Infection of seronegative, pregnant cows with BVDV often results in transplacentary transmission of the virus, thereby leading to a variety of reproductive losses. The consequences of intrauterine BVDV infection include transient infertility, embryonic death, fetal mummification, malformations, abortions, stilbirths and the birth of weak, unthrifty calves (Baker 1995). Nonetheless, a specific outcome of fetal infection assumes a paramount role in the epidemiology of BVDV, the production of persistently infected (PI) calves (McClurkin et al. 1984). Fetuses infected with NCP BVDV isolates between days 40 and 120 of gestational age may not succumb to infection. Rather, these fetuses often become immunotolerant to the infecting virus and are born persistently infected (PI) (McClurkin et al. 1984). The immunotolerance is virus-specific and PI calves are usually unable to mount an immune response to an antigenically identical or closely related virus (Coria \& McClurkin 1978, Brownlie et al. 1984, Bolin et al. 1985, Collen et al. 2000).

Persistently infected calves may be clinically normal and reach adult age, yet they are frequently undersized and unthrifty and often dye within the first months of life due to concurrent infections (Coria \& McClurkin 1978, McClurkin et al. 1979). These animals replicate the virus in a variety of tissues and shed virus in secretions and excretions for their lifetime. Superinfection of PI calves with an antigenically identical or very similar cytopathic (CP) virus, generally originated by genetic mutation/ recombination of the residing virus (Kummerer et al. 2000), results in a deadly clinical disease called mucosal disease (MD) (Brownlie et al. 1984, Bolin et al. 1985). The pathogenesis of $\mathrm{MD}$ and the exact role of the so called "pair" of BVDV CP and NCP viruses remain unclear.

We herein provide evidence that bovine fetuses exposed to multiple BVDV isolates concomitantly and born persistently infected may harbor mixed infections, thus replicating and shedding more than one challenge virus.

\section{MATERIALS AND METHODS}

All viruses, reagents and procedures used for the production of BVDV persistently calves have been described in details elsewhere (Arenhart et al. 2008). Briefly, eight PI calves were produced as part of an experiment designed to evaluate fetal protection conferred by an experimental, live attenuated BVDV vaccine. For this purpose, a group of non-vaccinated cows was challenged with a pool of BVDV isolates between days 60 and 90 of gestation. Challenge was performed by intranasal instillation of a viral suspension containing a total viral dose of $10^{7.5} \mathrm{TCID}_{50}$, with equivalent amounts of two Brazilian BVDV-1 isolates (SV-126.8 and UFSM-1) and two BVDV-2 (SV-63 and SV-260) (Flores et al. 2005). The pregnancy was monitored thereafter on a monthly basis by ultrassonographic examination and rectal palpation. Approximately one week after the predicted end of gestation, cows were submitted to hormone treatment to synchronize parturition. Blood samples for serology and virus isolation were obtained from newborn calves before the ingestion of colostrum and monthly up to day 210 , when the experiment was discontinued.

Virus isolation was performed by inoculating peripheral leucocytes obtained from heparinized blood into monolayers of MDBK cells. The presence of viral antigens was assessed by submitting inoculated cells to an indirect fluorescent antibody assay (IFA) three to five days later, using a pool of BVDV-specific monoclonal antibodies (MAbs) as primary antibodies (Corapi et al. 1990, Kreutz et al. 2000). Virus-neutralizing (VN) assays were performed by incubating two-fold dilutions of sera with 
approximately $100 \mathrm{TCID}_{50}$ of BVDV Singer or the respective homologous virus. Readings were performed after incubating the mixture serum-virus with MDBK cells for $72 \mathrm{~h}$, by visualization of cytopathic effect (for CP Singer strain) or by IFA of cell cultures. Virus isolation and VN assays were performed in blood/sera collected immediately after birth and then monthly up to day 210 of age.

The antigenic profile of viruses infecting PI calves was investigated by using a panel of MAbs (Corapi et al. 1990, Ridpath 2003, 2005). The Mab-antigenic profile of viruses recovered from $\mathrm{PI}$ calves was then compared to that of the parental viruses used for challenge. To this, leucocytes separated from blood collected approximately at day 30 of age were inoculated and co-cultivated with MDBK cells during five days. Cell monolayers were trypsinized, resuspended in culture medium and cell suspensions were deposited in multi-spot glass slides, left to attach, fixed in acetone and submitted to IFA, using different MAbs as primary antibodies. MDBK cells infected with each challenge virus, and mock-infected, were used as controls.

To investigate whether the PI calves harbored viruses of one or both genotypes, we used an RT-PCR for the 5'UTR of the viral genome that allows differentiation of viruses from different genotypes and subgenotypes (BVDV-1a and 1b) (Ridpath \& Bolin 1998). Briefly, leukocytes from blood collected at day 30 of age were separated by centrifugation and submitted to total RNA extraction using Trizol reagent. Total RNA was submitted to RT-PCR, using a set of primers that amplify only BVDV-1b (the two challenge viruses, SV-126.8 and UFSM-1 are BVDV-1b) or BVDV-2 sequences. The primer sequences and RT-PCR conditions have been described by Ridpath \& Bolin (1998).

\section{RESULTS AND DISCUSSION}

In a previous experiment, pregnant cows were challenged with a pool of BVDV isolates of different antigenic profiles to evaluate the spectrum of fetal protection conferred by an experimental, live attenuated vaccine containing BVDV1 and BVDV-2 genotypes (Arenhart et al. 2008). In the vaccinated group, protection was total and all cows delivered healthy, virus negative calves. In contrast, control cows had a variety of reproductive losses including abortion, stillbirths and the birth of PI calves. In the present study, eight calves born to control, unvaccinated cows were characterized regarding their virological and serological status.

The clinical, virological and serological status of calves born to dams inoculated with a pool of NCP BVDV isolates is presented in Table 1. Eight calves were born virus-positive and free of detectable levels of BVDV VN antibodies. Two of these calves were born undersized and weak (\# 1979 and 2156) and died at days 7 and 15 of age, respectively. Six calves were born healthy (\# 375, 382, 387, 395, 396 and 400) and were monitored thereafter. During the monitoring, these calves and their dams were maintained in separate pastures/barns to avoid cross-infection.

After confirmation that all calves were positive for virus at birth, a second testing (virus isolation and VN assays) was performed approximately 30 days later to confirm the status of persistent infection. At day 30, the survivor calves were still virus positive and had become positive for antibodies to BVDV (VN titers $>640$ ). The seropositivity of these calves at day 30 was likely due to colostrum-derived antibodies (Table 1). Monthly examination of these calves for virus in peripheral blood leucocytes up to day 210 yielded positive results. Periodic VN testing, as expected for passively acquired antibodies, resulted in gradual reduction of antibody titers and at day 210 none of the calves had detectable levels $(<2)$ of VN antibodies (Table 1). Monitoring the infectivity in the sera of these calves up to day 150 revealed persistent viremia in variable levels (Arenhart et al. 2009).

Upon confirming that the calves were persistently infected - two positive virus isolation results 30 days apart -, we asked whether these animals would harbor more than one virus since their dams had been challenged with a pool of BVDV isolates (Arenhart et al. 2008). As to investigate a possible co-infection in these $\mathrm{PI}$ animals, we used two approaches, taking advantage of the antigenic and genetic differences among the viruses used for challenge. First, we investigated the antigenic profile of $\mathrm{Pl}$-infecting viruses with a panel of MAbs, comparing it with the antigenic profile of challenge viruses. MDBK cells co-cultivated with blood leucocytes were submitted to IFA, using different MAbs as primary antibodies. Some of the MAbs were shown to react differentially with BVDV-1 or BVDV-2 (Ridpath 2003, 2004). The antigenic profile of the viruses recovered from peripheral leucocytes of PI calves, as ascertained by MAb binding, is shown in Figure 1, top panel.

The antigenic profile of viruses recovered from calves \#382 and 395 was very similar to the challenge virus SV126.8, and markedly differed from the other challenge viruses, indicating these animals were persistently infected with this BVDV isolate. Calves \# 387 and 375, in contrast, yielded viruses giving rise to a mixed antigenic profile.

Table 1. Clinical, virological and serological status of calves born to cows challenged with a pool of BVDV isolates between days 60 and 90 of gestation

\begin{tabular}{|c|c|c|c|c|c|c|c|c|c|c|}
\hline \multirow[t]{2}{*}{ Calf \# } & \multicolumn{3}{|c|}{ At birth } & \multicolumn{2}{|c|}{30 days } & \multicolumn{2}{|c|}{180 days } & \multicolumn{2}{|c|}{210 days } & \multirow[t]{2}{*}{ Observations } \\
\hline & Clinical & Virus & Antibodies & Virus & VN & Virus & VN & Virus & VN & \\
\hline 387 & Healthy & Positive & $<5$ & + & $>640$ & + & 40 & + & $<5$ & Healthy, normal growth \\
\hline 375 & Healthy & Positive & $<5$ & + & $>640$ & + & 40 & + & $<5$ & Healthy, normal growth \\
\hline 395 & Healthy & Positive & $<5$ & + & $>640$ & + & 10 & + & $<5$ & Healthy, died at 18 months, signs of MD \\
\hline 400 & Healthy & Positive & $<5$ & + & $>640$ & + & 20 & + & $<5$ & Healthy, died at 12 months, unrelated causes \\
\hline 382 & Healthy & Positive & $<5$ & + & $>640$ & + & 5 & + & $<5$ & Healthy, died at nine months, pneumonia \\
\hline 396 & Healthy & Positive & $<5$ & + & $>640$ & + & $<5$ & nt & $\mathrm{nt}$ & Healthy, died at 6 months, undiagnosed \\
\hline 1979 & Undersized & Positive & $<5$ & + & $>640^{\mathrm{a}}$ & $\mathrm{nt}$ & $\mathrm{nt}$ & nt & nt & Died 7 days after birth \\
\hline 2156 & Undersized & Positive & $<5$ & + & $>640^{a}$ & nt & nt & $\mathrm{nt}$ & nt & Died 15 days after birth \\
\hline
\end{tabular}




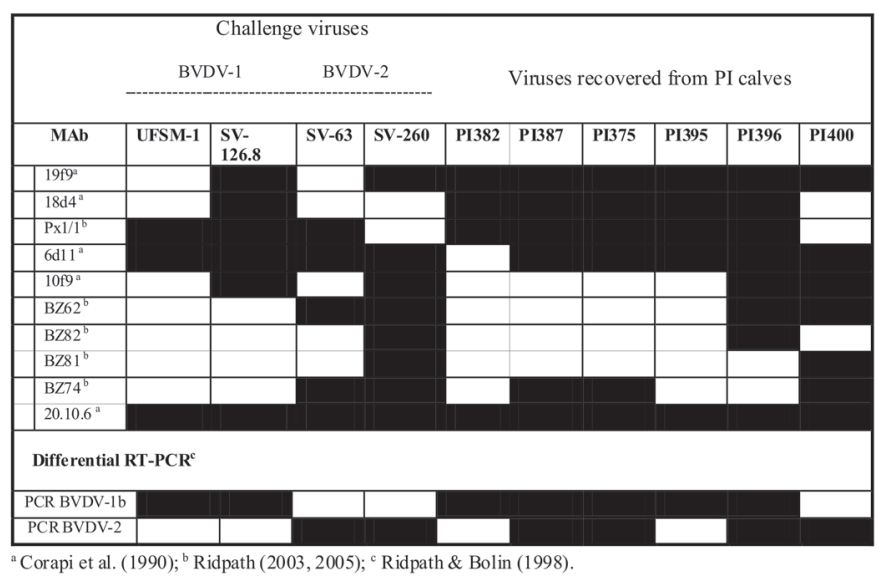

Fig.1. Reactivity of a panel of monoclonal antibodies (MAbs) with cells infected with challenge viruses and viruses obtained from PI calves (upper panel) and differential RT-PCR amplification of the genomes of these viruses (lower panel).

Reactivity with MAbs 1 to 3 is compatible with the profile of SV-126.8, yet binding of MAb 9 indicates the presence of a BVDV-2 as well (likely the isolate SV-63). Calf \# 396 also yielded virus with a mixed antigenic phenotype, suggesting co-infection with a BVDV-1 (likely SV-126.8) and BVDV-2 (probably SV-260). Finally, calf \# 400 yielded a virus whose profile of MAb binding is nearly identical to challenge isolate SV-260 (a BVDV-2) (Fig.1).

Therefore, analysis of the antigenic profile of the viruses recovered from the blood of $\mathrm{PI}$ calves suggested co-infection in three animals (\# 387, 375 and 396). In contrast, the viruses isolated from the other three calves displayed a single antigenic specificity. Interestingly, the isolate SV-126.8 seemed to be present in 5 out of 6 animals, either as a single virus or in a putative co-infection. The marked fetotropism and the ability to produce persistent infection of isolate SV-126.8 - a virus isolated from a healthy bovine fetus (Botton et al. 1998) - have already been demonstrated in experimental infections of pregnant sheep (Scherer et al. 2001).

In order to confirm the putative co-infection in these PI calves, we used a second approach, based on genetic differences in the 5'UTR of the viral genome (Ridpath \& Bolin 1998). A differential RT-PCRs able to distinguish BVDV-1 from BVDV-2 was then employed to amplify viral sequences present in leucocytes of $\mathrm{PI}$ calves collected at day 30 of age. The use of BVDV-1b-specific set of primers resulted in positive amplification (a 180bp amplicon) in RNA extracted from leucocytes of calves \# 375, 382, 387, 395 and 396 (Fig.1, bottom panel). The specificity of this PCR was confirmed by amplification of challenge viruses SV-126.8 and UFSM-1, but not SV-63 and SV-260 (not shown). The same was observed by amplifying RNA extracted from cells infected with the reference strain Singer, a BVDV-1 virus (not shown). Next, we submitted RNA extracted from leucocytes to a nested RT-PCR, whose second round is designed to amplify only sequences from BVDV-2 (Ridpath \& Bolin 1998). Positive results were obtained in samples of calves \# 387, 375, 396 and 400 . The specificity of this RTPCR was confirmed by positive amplification of challenge viruses SV-260 and SV-63 (BVDV-2), but not SV-126.8 and UFSM-1 (BVDV-1b). Three of these calves (\# 387, 375 and 396) also yielded PCR positive results by using BVDV-1b primers (Fig.1).

Thus, confirming the results of the MAb-binding antigenic profile, both single and mixed infections were detected in $\mathrm{PI}$ calves. Single positive results using BVDV-1b-specific primers were obtained by RT-PCR amplification of viral RNA present in leucocytes recovered from calves \# 382 and 395; calf \# 400 yielded a positive PCR result using BVDV-2specific primers. In contrast, RT-PCR tests performed on RNA extracted from leucocytes of three calves (\# 387, 375 and 396) yielded PCR results indicating mixed infections, resulting in amplification by both BVDV-1b and BVDV-2specific sets of primers (Fig.1). Therefore, the results of genotype-specific RT-PCR amplification reinforce the findings of the antigenic analyses, indicating mixed infections (BVDV1 and BVDV-2) in three PI calves born to dams challenged with a pool of BVDV isolates. Previously, Brock and Chase (2000) demonstrated dual infections in fetuses that had been exposed to an inoculum containing two different BVDV strains. Nonetheless, the fetuses were harvested 60 days after virus inoculation and were not allowed to go full term. Thus, dual persistence during all intrauterine and post-birth life was not demonstrated in that study.

Persistent infection is a frequent consequence of fetal infection with NCP BVDV during the first trimester of gestation, prior to the development of fetal immunocompetence (McClurkin et al. 1984, Baker 1995). PI calves are usually unable to mount an immune response to the infecting virus, presumably due to immunological tolerance (Coria et al. 1978, McClurkin et al. 1979, 1984). The immunological basis for the tolerance is a matter of debate and both specific B- and T-CD4-cell depletion have been implicated (Collen et al. 2000, Liu et al. 2009). The failure to respond immunologically is specific for residing virus and, superinfection with an identical or antigenically very similar CP virus leads to an uncontrolled replication of the superinfecting virus and the development of mucosal disease (MD) (Brownlie et al. 1984, Bolin et al. 1985). In any case, $\mathrm{PI}$ animals are able to respond immunologically to antigenically different virus yet are unresponsive or weakly responsive to antigenically identical or very similar viruses (Coria \& McClurkin 1978, Brownlie et al. 1984, Collen et al. 2000).

In the present study, PI calves were monitored for up to 210 days; a few were kept and monitored even longer. During this time, calves continuously harbored the virus in blood, at variable levels, and continuously shed the virus in body secretions and excretions (Arenhart et al. 2009). After the disappearance of passive immunity, testing the sera of these animals by VN against the homologous virus (either one or two, in the putative co-infections) at different intervals revealed no detectable $\mathrm{VN}$ antibodies (not shown). Thus, these calves seemed to be unable to respond 
immunologically to both persisting viruses. Unfortunately, we were unable to keep most of these PI calves longer and the experiment was discontinued.

In summary, our results indicate that infection of pregnant cows with a mixture of NCP BVDV isolates may result in the birth of $\mathrm{PI}$ calves harboring more than one challenge virus. Thus, under experimental conditions, persistent infection by BVDV may be established by more than one virus concomitantly. Whether similar condition would occur in nature and, if so, its possible implication in the pathogenesis, epidemiology and control of BVDV infection are unclear at this point. In any case, these findings add a new interesting piece of information on the biology of BVDV. The study of mixed persistent infections with antigenically distinct viruses and may help in understanding the immunological and molecular basis of BVDV-induced immunological tolerance and persistence.

\section{REFERENCES}

Arenhart S., Silva L.F., Henzel A., Ferreira R., Weiblen R. \& Flores E.F. 2008. Proteção fetal contra o vírus da diarréia viral bovina (BVDV) em vacas prenhes previamente imunizadas com uma vacina experimental atenuada. Pesq. Vet. Bras 28(10):461-470.

Arenhart S., Bauermann F.V., Oliveira S.A., Weiblen R. \& Flores E.F. 2009. Excreção e transmissão do vírus da diarréia viral bovina por bezerros persistentemente infectados. Pesq. Vet. Bras. 29(9):736742.

Baker J.C. 1995. The clinical manifestations of bovine viral diarrhea virus infection. Vet. Clin. North Am. 11(3):425-445.

Botton S.A., Silva A.M., Brum M.C.S., Flores E.F. \& Weiblen R. 1998. Antigenic characterization of Brazilian bovine viral diarrhea virus isolates by monoclonal antibodies and cross-neutralization. Braz. J. Med. Biol. Res. 31(11):1429-1438.

Bolin S.R., McClurkin A.W. \& Cutlip R.C. 1985. Severe clinical disease induced in cattle persistently infected with noncytophatic bovine viral diarrhea virus by superinfection with cytophatic bovine viral diarrhea virus. Am. J. Vet. Res. 46:573-576.

Brock K.V. \& Chase C.C.L. 2000. Development of a fetal challenge method for the evaluation of bovine viral diarrhea virus vaccines. Vet. Microbiol. 77:209-214.

Brownlie J., Clarke M.C. \& Howard C.J. 1984. Experimental production of fatal mucosal disease in cattle. Vet. Rec. 114:535-536.

Collen T., Douglas A.J., Paton D.J., Zhang G. \& Morrison I.W. 2000. Single amino acid differences are sufficient for CD4+ T-cell recognition of a heterologous virus by cattle persistently infected with bovine viral diarrhea virus. Virology 276:70-82.

Corapi W.V., Donis R.O. \& Dubovi E.J. 1990. Characterization of a panel of monoclonal antibodies and their use in the study of the antigenic diversity of bovine viral diarrhea virus. Am. J. Vet. Res. 51:1388-1394.
Coria M.F. \& McClurkin A.W. 1978. Specific immune tolerance in an apparently healthy bull persistently infected with bovine viral diarrhea virus. J. Am. Vet. Med. Assoc. 172:449-451.

Fauquet M.A., Mayo J., Maniloff U., Desselberger A.L. \& Ball L.A. 2005. Virus Taxonomy: $8^{\text {th }}$ Report of the International Committee on Taxonomy of Viruses. Springer-Verlag, New York. 1162p.

Flores E.F., Ridpath J.F., Weiblen R., Vogel F.S.F. \& Gil L.H.V.G. 2002. Phylogenetic analysis of Brazilian bovine viral diarrhea virus type 2 (BVDV-2) isolates: evidence for a subgenotype within BVDV2. Virus Res. 87:51-60.

Flores E.F., Weiblen R., Vogel F.S.F., Roehe P.M., Alfieri A.A. \& Pituco E.M. 2005. A infecção pelo vírus da Diarréia Viral Bovina (BVDV) no Brasil: histórico, situação atual e perspectivas. Pesq. Vet. Bras. 25:25-134.

Fulton R.W., Ridpath J.F., Confer A.W., Saliki J.T., Burge L.T. \& Payton M.E. 2003. Bovine viral diarrhoea virus antigenic diversity: Impact on disease and vaccination programmes. Biologicals 31:89-95.

Kreutz L.C., Donis R.O., Gil L.H.V.G., Hoffman A.N., Garcez D.C., Flores E.F. \& Weiblen R. 2000. Production and characterization of monoclonal antibodies to Brazilian isolates of bovine viral diarrhea virus. Braz. J. Med. Biol. Res. 33(12):1459-1466.

Kummerer B.M., Tautz N., Becher P., Thiel H. \& Meyers G. 2000. The genetics basis for cytopathogenicity of pestiviruses. Vet. Microbiol. 77:117-128.

Larsson B., Fossum C. \& Juntti N. 1990. In vitro production of antibodies to bovine virus diarrhoea virus by peripheral blood mononuclear cells from cattle immunised by infection. Vet. Microbiol. 22:161-170.

Liu L., Xia H., Wahlberg N., Belák S. \& Baule C. 2009. Phylogeny, classification and evolutionary insights into pestiviruses. Virology 385(2):351-357.

McClurkin A.W., Littledike E.T. \& Cutlip R.C. 1979. Reproductive performance of apparently healthy cattle persistently infected with bovine viral diarrhea virus. J. Am. Vet. Med. Assoc. 174:1116-1119.

McClurkin A.W., Littledike E.T., Cutlip R.C., Frank G.H., Coria M.F. \& Bolin S.R. 1984. Production of cattle immunotolerant to BVD virus. Can. J. Comp. Med. 48:156-161.

Pellerin C., Hurk J., van den Lecomte J. \& Tussen P. 1994. Identification of a new group of bovine viral diarrhea virus strains associated with severe outbreaks and high mortalities. Virology 203(2):260-268.

Ridpath J.F. 2003. BVDV genotypes and biotypes: Practical implications for diagnosis and control. Biologicals 31:127-131.

Ridpath J.F. 2005. Practical significance of heterogeneity among BVDV strains: Impact of biotype and genotype on U.S. control programs. Prev. Vet. Med. 72(1/2):17-30.

Ridpath J., Bolin S. \& Dubovi E. 1994. Segregation of bovine viral diarrhea virus into genotypes. Virology 205:66-74.

Ridpath J.F. \& Bolin S.R. 1998. Differentiation of types 1a, 1b e 2 bovine viral diarrhea virus (BVDV) by PCR. Mol. Cell. Probes. 12:101-106.

Scherer C.F.C., Flores E.F., Weiblen R., Caron L., Irigoyen L.F., Neves J.P. \& Maciel M.N. 2001. Experimental infection of pregnant ewes with bovine viral diarrhea virus type-2 (BVDV-2): Effects on pregnancy and fetus. Vet. Microbiol. 77:285-299. 